\title{
HOOKED ON LIT SCREENS
}

\section{Enganchados a las pantallas}

\section{Enrique Guerrero, Patricia Diego, and David Kimber}

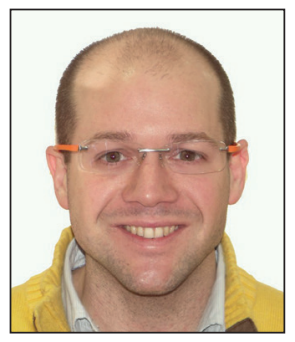

Enrique Guerrero is a professor at the School of Communication of the Universidad de Navarra (Spain), and assistant director of the Department of Film, TV, \& Digital Media. He has been a visiting scholar at the University of California Los Angeles, Bournemouth University, The University of Texas at Austin, and the University of Piura. His research is focused on the impact of digitalization in the audiovisual industry, especially on the production standards of entertainment shows. http://orcid.org/0000-0001-7693-8669
Universidad de Navarra, School of Communication Campus Universitario. 31009 Pamplona, Spain eguerrero@unav.es

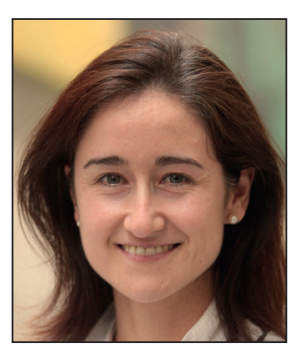

Patricia Diego is a professor at the School of Communication, Universidad de Navarra (Spain), and director of the Department of Film, TV \& Digital Media. She got a PhD in 2004 with an outstanding doctoral thesis award. On top of that, she has been a visiting researcher at the University of Westminster (UK) and the University Collage Cork (Ireland). Her current lines of research are production standards in TV drama and the impact of digitalization on the TV industry. http://orcid.org/0000-0002-7616-2474
Universidad de Navarra, School of Communication Campus Universitario. 31009 Pamplona, Spain pdiegon@unav.es

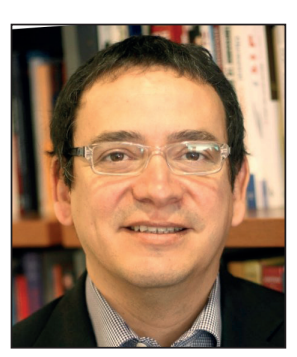

David Kimber is assistant professor of Marketing and program director of the Master of Science in Marketing at the School of Business and Economics, Universdad de los Andes (Chile). He received his Commercial Engineering degree in 1994, his MBA (1999) and MSc. in Management (2012) all from the Catholic University of Chile, and he has a $\mathrm{PhD}$ (c) from the School of Communication, University of Navarra (Spain). His research interests are consumer behavior, communication, advertising, and audiovisual product quality.

http://orcid.org/0000-0002-3006-9231

Universidad de los Andes, School of Business and Economics Mons. Álvaro del Portillo. 12455 Las Condes (Santiago), Chile dkimber@uandes.cl

\begin{abstract}
The aim of this article is to trace new audiovisual consumption habits, analyzing which screens are preferred by people in Spain when watching different types of content online. In addition, we study the use of second screens, an increasingly common phenomenon. The main sources of data for this empirical study are two original surveys carried out online in May 2012 and in December 2016. The sample size was 1,200 in both cases, and interviews were conducted via the Internet. The target population consisted of Internet users in Spain and the sample distribution was designed to be representative of this population. Our results show that audiovisual consumption habits are changing dramatically, especially when looking at younger users, whose loyalty and attention is even more difficult to attract due to their disruptive practices. In this sense, great uncertainties and risks have emerged in the entertainment industry, although valuable opportunities may also arise.
\end{abstract}

\section{Keywords}

Audiences; Audiovisual content; Internet users; Screens; Online viewing; Television.

\section{Resumen}

El objetivo de este artículo es descubrir nuevos hábitos de consumo audiovisual, analizando cuáles son las pantallas preferidas por los internautas españoles para ver contenidos audiovisuales online. Además, se analiza el uso de las segundas pantallas, práctica muy extendida entre la audiencia. La principal fuente de información es un estudio de campo basado en dos encuestas online originales lanzadas en mayo de 2012 y en diciembre de 2016. La muestra se compone en ambos casos de 1.200 personas y es representativa de la población internauta en España (universo). Los resultados apuntan a que los patrones de consumo audiovisual están cambiando drásticamente, especialmente en el caso de los usuarios más jóvenes, cuya fidelidad y atención es incluso más difícil de atraer debido a sus prácticas disruptivas. En este sentido, la industria del 
entretenimiento atraviesa una etapa repleta de importantes incertidumbres y riesgos, aunque al mismo tiempo se vislumbran valiosas oportunidades.

\section{Palabras clave}

Audiencias; Contenidos audiovisuales; Internautas; Pantallas; Televisión; Visionado online.

Guerrero, Enrique; Diego, Patricia; Kimber, David (2017). “Hooked on lit screens”. El profesional de la información, v. 26, n. 6, pp. 1108-1117.

https://doi.org/10.3145/epi.2017.nov.10

\section{Introduction}

A decade ago, the traditional television set was practically the only way to watch audiovisual content in Spain. Although it was possible, of course, to access audiovisual content online via such platforms as YouTube or the first Internet-connected services offered by legacy TV operators (Guerrero, 2011; Diego, 2015), it was not yet a popular option due to technical limitations and because the range of content on offer was likewise limited. Nowadays, however, the emergence of a wide range of Internet connected devices and the roll-out of high-speed wireless communication networks have radically transformed audiovisual viewing habits in Spain. Some recent research claims that we are now in the post-broadcasting era (Tse, 2016). Currently, audiences can avail themselves of a variety of devices to access content, including computers, tablets, and smartphones. This change has been led by the youngest segment of the population, which has pioneered the adoption of new technologies (González-Aldea; López-Vidales, 2011).

The impact of digitalization on audiences and consumption habits alike has been addressed by a large number of experts, who have studied the emergence of digital culture and its consequences for media and entertainment (Jenkins, 2006; Tapscott, 2009; Jenkins; Ford; Green, 2013). Several researchers have also directly explored the relationship between television, new media, and the Internet (Palmer, 2006; Vukanovic, 2009; Doyle, 2010; Evens, 2010; Gunter, 2010) and their implications for media management (Anderson, 2006; Ulin, 2013; Voguel, 2014; Doyle, 2015). Previous studies about the evolution of consumption habits are important for the purposes of this study (Evans, 2011; Napoli, 2011; Bondad-Brown; Rice; Pearce, 2012; Taneja et al., 2012; Bury; Li, 2013), especially those that address the use of second screens and its challenges (Park, 2013; Galindo-Rubio; Fernández-Blanco; Alameda-García, 2014; Abreu et al., 2015; Choi; Jung, 2016).

In the case of Spain, such issues have been addressed from a number of research perspectives including the interrelationships between television, convergence, business models, and new technologies (Arrojo, 2010; Artero, 2010; Micó-Sanz, 2010; Izquierdo-Castillo, 2012; Feijóo, 2013; Guerrero; Diego; Pardo, 2013; Fernández-Manzano; Neira; Clares-Gavilán, 2016); the impact of technological innovation on viewing habits (Lacalle, 2011; Castillo-Hinojosa, 2012; Alonso; Broullón-Lozano; Lamuedra-Graván, 2016); and, in particular, how younger users are leading the way in new consumer behaviors (Galán-Fajardo; Del-Pino-Romero, 2010; Méndiz; De-Aquilera; Borges, 2011; López-Vidales; Gómez-Rubio, 2014).

As a reading of the relevant academic literature reveals, not only have the interconnected multiplatform environment and digitalization had an impact on audience viewing habits, they have also had a profound impact on the audiovisual industry itself in terms of its production and distribution processes (Doyle, 2016), as well as on the business models that underpin it. As a result, the main players in the sector now face new challenges and new competitors such as subscription video on demand (S-VOD) services like Netflix, HBO Go, and Amazon Prime, as well as other online video platforms, such as YouTube, a company that has started to show more and more interest in the professional quality of its offer and the production of its own content. A number of research studies have explored the links between traditional operators (TV networks and production companies) and these online services (Kim, 2012; Jiyoung, 2013; Cunningham; Craig; Silver, 2016).

The purpose of this paper is to outline how the audiovisual viewing habits of Spanish Internet users has developed in recent years (2012-2016) with regard to the type of content they watch (fiction series, entertainment programs, films, news, sports, etc.), and whether the devices they use are complementary or exclusive (smart TV set, smartphones, tablets, and computers), as well as the use of interactive applications and second screens.

Although the motivations underlying the consumption habits addressed here are not the main focus of inquiry, the uses and gratifications theory provides a theoretical framework for our study. A number of our conclusions support the idea that, despite dramatic technological change, the needs people endeavor to meet via online audiovisual media are not so different from those first discussed in the 1970 s by researchers such as Katz, Gurevitch, and Hass (1973).

The results of this study are of interest to the audiovisual industry as a whole -TV networks, production companies, distributors, etc.- in terms of content creation and product scheduling across a variety of platforms. In order to make creative decisions that include high-risk economic costs, media producers need to know as much as possible about audiences and their viewing habits. In this regard, this article fills the space in-between audience and production studies (Mayer, 2016). 


\section{Methodology}

Our study is based on two online surveys, one administered in May 2012 and the other in December 2016. The sample comprised Spanish Internet users, who are defined by AIMC (Spanish Media Research Association) as individuals who are between the ages of 14 and 65 years old and who have accessed the Internet at least once in the last month. Currently, $78.6 \%$ of this age group are Internet users (AIMC, 2017), amounting to approximately 28 million people in Spain (INE, 2017).

The data collection was carried out via Internet user panels provided by Netquest, a marketing research company. Proportional quotas were established for the categories of sex, age, and region. The final sample mirrors the structure of the theoretical sample. Both surveys generated high response rates and the sample size was 1,200 (Table 1).

The research questions addressed by this study are as follows:

- What percentage of Spanish Internet users watch audiovisual content online?

- What screens are most commonly used for this purpose and are they used simultaneously?

- What types of content are most frequently viewed via the Internet?

- Is there is a relationship between the media device used and the type of content viewed?

- What are the most popular interactive applications?

- Does viewing audiovisual content online affect the time spent watching linear television?

\section{Results: matching screens, contents, and users}

The data collected from the 2016 survey is presented below, and compared with the results from the 2012 survey in order to describe the evolution in online audiovisual content viewing habits in recent years ${ }^{1}$.

To start the discussion, an overview of how legacy TV viewing in Spain has evolved over the last ten years may be worthwhile. Table 2 shows a rising trend in linear television consumption up to the year 2012, when the figures reached a peak number of minutes viewed per person per day (246 minutes). However, a downturn set in from 2013 onwards, when the average number of television viewing minutes started to fall steadily. In just four years, the average figure fell by a total of 16 minutes per person, which is quite a steep decrease.

This decrease is due to a number of factors, some of which are only indirectly related to the audiovisual sector, such as the financial crisis and recovery. There are other factors, however, that have a much more direct bearing on the situation.

\section{Almost $65 \%$ of users acknowledge that} they spend less time watching conventional television due to the availability of other audiovisual platforms online

First, although it was set up initially in 2008, Radio Televisión Española, the Spanish public broadcasting network, relaunched its a-la-carte online service, RTVE A la carta, in 2011. In late 2011, Mediaset España launched its multiscreen television (catch-up TV) service called Mitele, which packages its TV channel programming for online access. Two years later, in 2013, Atresmedia rolled out an equivalent service called Atresplayer, a merged brand for online services offered by its channels. In short, between 2011 and 2013, the multi-

Table 2. Evolution of TV consumption in Spain. Average minutes per day

\begin{tabular}{|l|c|c|c|c|c|c|c|c|c|c|}
\cline { 2 - 11 } \multicolumn{1}{c|}{} & $\mathbf{2 0 0 7}$ & $\mathbf{2 0 0 8}$ & $\mathbf{2 0 0 9}$ & $\mathbf{2 0 1 0}$ & $\mathbf{2 0 1 1}$ & $\mathbf{2 0 1 2}$ & $\mathbf{2 0 1 3}$ & $\mathbf{2 0 1 4}$ & $\mathbf{2 0 1 5}$ & $\mathbf{2 0 1 6}$ \\
\hline Linear & 223 & 227 & 226 & 234 & 239 & 246 & 244 & 239 & 234 & 230 \\
\hline Non-linear & & & & & & & & \\
\hline Total & 223 & 227 & 226 & 234 & 239 & 246 & 244 & 239 \\
\hline
\end{tabular}

Source: Kantar Media. 


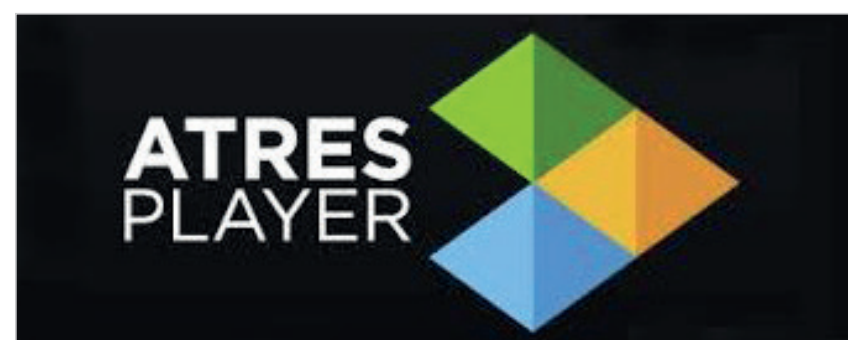

http://www.atresplayer.com

platform and online services that were offered by the main commercial TV operators in Spain were consolidated, during a time in which the existing audience rating tools took into account only traditional television viewing. At that time, besides the personal video recorder (PVR), Kantar Media had not installed a cross-media audience measurement device, although some pilot testing had been carried out, so no combined data (linear and non-linear) is available. These figures were not available until 2015, albeit still in a preliminary form.

In addition, from 2014 onwards the pay-per-view television market in Spain began to expand dramatically due to the inclusion of these services on mobile telephones, landline and internet access packages offered by telecommunications companies. In March 2014, for instance, Movistar, one of the leading Spanish telecoms, launched Movistar Fusión TV, which prompted its major competitors to do likewise shortly afterwards. To a considerable extent, the attractiveness of such offers was not based on the package of conventional television channels, but on the added value of supplementary features, such as OTT (over-the-top television) platforms, which provided other content as well as television products. In this regard, Movistar bought Canal+ in 2015, rebranding itself as Movistar+ and incorporating the on-demand video service Yomvi. By means of such strategies, television operators launched services that competed with their own linear television programming at a time when, as noted above, audiovisual viewing of that kind was not taken into account by audience rating tools.

In 2015, other new subscription video-on-demand (S-VOD

Table 3. Impact of online audiovisual consumption on traditional TV viewing (\%)

\begin{tabular}{|l|r|}
\hline Yes, it has an impact: I watch more traditional TV & 5.5 \\
\hline Yes, it has an impact: I watch less traditional TV & 63.4 \\
\hline $\begin{array}{l}\text { No, it has no impact. I watch the same amount of traditio- } \\
\text { nal TV }\end{array}$ & 31.1 \\
\hline Total & 100 \\
\hline
\end{tabular}

Table 4. User gender and online viewing (2016) (\%)

\begin{tabular}{|l|c|c|c|}
\cline { 2 - 4 } & $\begin{array}{c}\text { Does not watch } \\
\text { online content }\end{array}$ & $\begin{array}{c}\text { Watches onli- } \\
\text { ne content }\end{array}$ & Total \\
\hline Male & 18.7 & 81.4 & 100 \\
\hline Female & 22.3 & 77.7 & 100 \\
\hline Total & 20.5 & 79.5 & 100 \\
\hline
\end{tabular}

Pearson chi2 $[1]=3.1465, p=0.076$

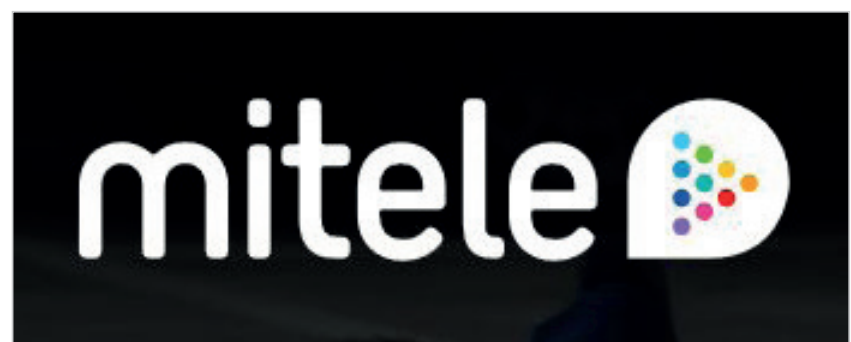

http://www.mitele.es

or OTT) services such as Netflix also entered the Spanish market, followed in 2016 by HBO España and Amazon Prime Video, and Sky in 2017. These services joined other such platforms that were already established in the market, including Filmin and Rakuten TV (Wuaki TV), among others, as well as such popular online video sites as YouTube. As a result, in a relatively short period of time the Spanish market has moved from famine to feast in audiovisual terms.

What impact has the proliferation of wide-ranging online and on-demand video services had on traditional television consumption? Table 3 shows that the availability of audiovisual content online has a direct impact on the amount of time spent viewing traditional TV programming. $63.4 \%$ of users acknowledge that they spend less time watching conventional television due to the availability of other platforms.

In 2012, the data from our study prompted the conclusion that television consumption was not negatively impacted by competition from online services. Nevertheless, four years later, following the boom in the number and range of such content, the situation had changed dramatically.

The results of the 2016 survey show that $79.5 \%$ of Internet users watch audiovisual content online (Table 4). In contrast, in 2012, this figure was only $42.3 \%$. At present, no significant differences are discernible with regard to the sex of the average viewer, as $81.4 \%$ of men and $77.7 \%$ of women say that they access audiovisual content online (Table 4). However, a clear conclusion may be drawn in relation to audience age-segments: the youngest segments (14-24 and 25-34 years old) are by far the most likely to view audiovisual content online (97.5\% and 92.6\%) (Table 5).

Around $20 \%$ of Internet users say that they never or almost never watch videos online (Tables 4 and 5), most of whom $(66 \%)$ add that they do not do so because they prefer to view them via traditional media such as conventional televi-

Table 5. Use age-segments and online viewing (2016) (\%)

\begin{tabular}{|l|c|c|c|}
\cline { 2 - 4 } \multicolumn{1}{c|}{} & $\begin{array}{c}\text { Does not watch } \\
\text { online content }\end{array}$ & $\begin{array}{c}\text { Watches online } \\
\text { content }\end{array}$ & Total \\
\hline $14-24$ & 2.5 & 97.5 & 100 \\
\hline $25-34$ & 7.4 & 92.6 & 100 \\
\hline $35-44$ & 18.5 & 81.5 & 100 \\
\hline $45-54$ & 31.5 & 68.5 & 100 \\
\hline $55-65$ & 38.3 & 61.7 & 100 \\
\hline Total & 20.5 & 79.4 & 100 \\
\hline
\end{tabular}

Pearson chi2[4] $=144.1602, p=0.000$ 
Table 6. Reasons for not viewing audiovisual content online (2016) (\%)

\begin{tabular}{|l|l|}
\hline Because I prefer watching TV or going to the cinema & 66 \\
\hline Because I don't have a good Internet connection & 10 \\
\hline Because it's difficult to find the content & 3 \\
\hline Because I'm not interested & 13 \\
\hline Because the image or sound quality is poor & 3 \\
\hline Because I don't have time & 23 \\
\hline Other reasons & 2 \\
\hline
\end{tabular}

sion or cinema outlets (Table 6). The correct interpretation of these data may be contextualized by recalling that most of this latter group are people over the age of 55 (Table 5), whose viewing habits on conventional media are long established. The second most prevalent reason cited is lack of time (23\%).

The youngest segments of the population (14-24 and 25-34 years old) are by far the most likely to view audiovisual content online (97.5\% and 92.6\%)

The next table details information relating to a key issue addressed in this paper. The research questions covered here include the following: what types of television content are most frequently viewed online; what screens are most commonly used for this purpose; and is there a relationship between the media device used and the type of content viewed.

The data presented in Table 7 shows that films, foreign scripted series, and news (in that order) are the most frequently viewed content among users who watch video via the Internet. As compared with the 2012 data, there has rtve.es

\section{A la carta \\ Televisión y Radio}

http://www.rtve.es/alacarta

been an increase in almost all program genres, especially in the miscellaneous category referred to as "Other", which encompasses a range of content including educational and cultural, musical, documentary, and user-generated products (posted to platforms such as YouTube). Movies have replaced foreign fiction series as the content-type that is most frequently viewed online.

The main conclusion with regard to the relationship between screens and content is that larger screens like televisions (be it smart TV or a set connected to the Internet via a third device) and computers tend to be used to watch content that require continuous viewing and a higher level of concentration, such as films and TV series. In contrast, the smallest-sized screen, the smartphone, tend to be used to watch content that can be viewed in a more fragmented way or while on the move, such as news-related videos. Although some of the fine detail of the data involved may vary in this regard, the overall patterns of consumption have remained stable between 2012 and 2016.

The computer and the smartphone are, by far, the most frequently used devices: almost $90 \%$ of Internet users watch online content on the computer, and around $74 \%$ on the smartphone (Table 7). Table 8 lists the devices used for this purpose with regard to its frequency. In the case of the com-

Table 7. Audiovisual content viewed online on different screens (2016) (\%)

\begin{tabular}{|c|c|c|c|c|c|c|c|c|}
\hline Device/Content & $\begin{array}{l}\text { Spanish } \\
\text { series }\end{array}$ & $\begin{array}{c}\text { Foreign } \\
\text { series }\end{array}$ & $\begin{array}{c}\text { Enter- } \\
\text { tainment } \\
\text { programs }\end{array}$ & Films & $\begin{array}{c}\text { News pro- } \\
\text { grams }\end{array}$ & Sports & Other & $\begin{array}{c}\text { Users per } \\
\text { device }\end{array}$ \\
\hline Computer & 35.7 & 51.9 & 36.9 & 63.4 & 42.6 & 31.3 & 57.1 & 89.3 \\
\hline Smartphone & 10.5 & 13.0 & 15.5 & 12.3 & 50.9 & 17.0 & 61.5 & 73.8 \\
\hline Tablet & 19.6 & 29.4 & 23.1 & 31.9 & 27.9 & 20.1 & 43.8 & 53.0 \\
\hline Smart TV & 49.4 & 56.9 & 51.6 & 68.4 & 34.7 & 37.6 & 49.6 & 40.5 \\
\hline TV connected to the Internet & 32.4 & 41.8 & 28.8 & 55.9 & 21.4 & 26.1 & 33.4 & 43.3 \\
\hline Any platform & 60.1 & 74.3 & 61.7 & 88.3 & 73.6 & 49.8 & 82.8 & \\
\hline
\end{tabular}

Table 8. Use of different screens to watch audiovisual content online (2016) (\%)

\begin{tabular}{|l|c|c|c|c|c|}
\hline \multicolumn{1}{|c|}{ Device/Frequency } & $\begin{array}{c}\text { Never or al- } \\
\text { most never }\end{array}$ & Once a month & $\begin{array}{c}\text { At least once a } \\
\text { week }\end{array}$ & $\begin{array}{c}\text { At least three } \\
\text { times a week }\end{array}$ & Every day \\
\hline Computer & 10.7 & 13.9 & 23.5 & 23.5 & 28.6 \\
\hline Smartphone & 26.2 & 13.8 & 20.6 & 16.2 & 100 \\
\hline Tablet & 47.0 & 16.0 & 16.9 & 11.6 & 8.6 \\
\hline Smart TV & 59.5 & 8.8 & 13.2 & 100 & 9.5 \\
\hline TV connected to the Internet* & 56.7 & 10.1 & 13.7 & 10.7 & 8.0 \\
\hline
\end{tabular}

* This category refers to television sets connected to the Internet via a third device: games console, Apple TV, Google Chromecast, or similar. 
Table 9. Screens used simultaneously while viewing online content (2016) (\%)

\begin{tabular}{|c|c|c|c|c|c|c|}
\hline \multirow[b]{2}{*}{ Device used as primary screen } & \multicolumn{6}{|c|}{ Device used as second screen } \\
\hline & Computer & Smartphone & Tablet & Smart TV & $\begin{array}{l}\text { TV connected } \\
\text { to the Internet }\end{array}$ & $\begin{array}{l}\text { No second } \\
\text { screen }\end{array}$ \\
\hline Computer & & 48.7 & 13.6 & 11.2 & 12.5 & 36.1 \\
\hline Smartphone & 45.0 & & 17.3 & 18.7 & 14.2 & 34.1 \\
\hline Tablet & 19.9 & 34.0 & & 16.5 & 13.2 & 39.7 \\
\hline Smart TV & 23.5 & 52.5 & 22.9 & & 11.4 & 25.7 \\
\hline TV connected to the Internet & 29.2 & 42.0 & 17.2 & 9.5 & & 30.0 \\
\hline
\end{tabular}

puter, $28.6 \%$ of Internet users view content via this screen every day, and $23.5 \%$ at least three times a week, meaning that more than $50 \%$ of the online population use the computer for this purpose several times a week. The figures for the smartphone are slightly lower, but noteworthy nonetheless: $23.3 \%$ every day and $16.2 \%$ three times a week. That is, almost $40 \%$ of Internet users use their smartphone to access audiovisual content several times per week.

The use of both computers and smartphones has increased dramatically in recent years. However, the increase in tablet use has been moderate at best, peaking at slightly less than $9 \%$ for daily use. A striking figure in this data is around $60 \%$ of those surveyed say they never or almost never access online audiovisual content via Internet-connected or smart TV sets. For the most part, the traditional household television set continues to be used to watch conventional TV programming, not as a means of accessing online video services. Comparing the data for traditional television use between 2012 and 2016 shows that the use of this screen has now stagnated.

\section{Almost $80 \%$ of Internet users watch au- diovisual content online}

In addition, a common audience profile is the multitasking viewer (Tapscott, 2009; Arrojo, 2010) or double dipper (Gunter, 2010); that is, users who watch television and surf the Internet, commenting on or sharing content via social networking sites at the same time. It reveals a symbiotic relationship between TV and the Internet through which the role of each medium is mutually reinforced, especially when young audiences are involved. So, the internet cannot be regarded merely as a competitor; rather, it enriches other media, offering a new platform by means of which the audien- ce may be engaged (Gunter, 2010). As the data presented here show that "second screen" use -watching audiovisual content while simultaneously carrying out other activities on a second device- is now a widespread practice.

\section{Movies, foreign fiction series, and news}

are the most frequently viewed content. Computers and smartphones are, by far, the most frequently used devices

The figures in Table 9 reflect that the smartphone is the most commonly used second screen device. If the smartphone is used as the primary device, a secondary device is rarely used with it, with the exception of the computer; over a third of users (34.1\%) state that they use their smartphone exclusively. In contrast, $52.5 \%$ of users say that they also look at their mobile phone while using their smart TV set. And finally, almost $40 \%$ of those who access content using their tablets don't choose a second screen.

In short, the second screen is always smaller in size than the first, except if the smartphone is used as the main screen. For this reason, smart TV and Internet-connected TV sets are rarely used as second screens, whereas -as the data clearly show- the smartphone functions as the ideal complementary device in this regard.

Over $60 \%$ of viewers commonly use the following interactive applications on a second device while watching audiovisual content on a first screen, a figure that marks quite a significant increase (14\%) on the equivalent proportion in 2012. $35.2 \%$ of users always have a second screen in hand while watching audiovisual content, while $27.9 \%$ often do (Table 10). WhatsApp and other messaging services are by far the most popular apps, followed by social networks.

Table 10. Interactive applications used simultaneously while viewing online content (2016) (\%)

\begin{tabular}{|c|c|c|c|c|c|}
\hline Use/Frequency & Never & Rarely & Occasionally & Often & Always \\
\hline Email & 30.6 & 17.3 & 24.0 & 15.0 & 13.1 \\
\hline Social networks (Facebook, Twitter, Linkedln, Instagram, or others) & 27.8 & 16.1 & 22.0 & 18.7 & 15.4 \\
\hline WhatsApp or other messaging services & 18.4 & 9.4 & 25.1 & 22.2 & 24.9 \\
\hline Chatrooms or forums & 59.4 & 17.3 & 13.9 & 5.7 & 3.8 \\
\hline Browse the web & 27.3 & 16.6 & 26.3 & 17.2 & 12.6 \\
\hline Use other applications & 34.5 & 19.2 & 25.6 & 12.7 & 8.0 \\
\hline Voice calls & 55.2 & 18.9 & 15.1 & 6.0 & 4.9 \\
\hline Any of these activities & 9.2 & 5.4 & 22.3 & 27.9 & 35.2 \\
\hline
\end{tabular}


Table 11. Use of interactive applications relating to audiovisual content, either at the moment of viewing or later (2016) (\%)

\begin{tabular}{|c|c|c|c|c|c|}
\hline Use/Frequency & Never & Rarely & Occasionally & Often & Always \\
\hline Websites, blogs, and online forums & 29.4 & 23.1 & 26.8 & 13.2 & 7.5 \\
\hline Social networks (Facebook, Twitter, LinkedIn, Instagram, or others) & 17.2 & 12.1 & 21.1 & 22.9 & 26.8 \\
\hline Messages, e-mails, WhatsApp, or other messaging applications & 9.7 & 10.7 & 20.7 & 21.8 & 37.2 \\
\hline Download applications and content & 20.3 & 17.8 & 27.0 & 20.9 & 14.0 \\
\hline $\begin{array}{l}\text { View complementary content (making of, interviews with actors, } \\
\text { exclusive online episodes, etc.) }\end{array}$ & 31.7 & 24.4 & 25.4 & 13.1 & 5.4 \\
\hline Videogames based on TV series and programs & 59.9 & 15.3 & 14.4 & 7.4 & 3.1 \\
\hline
\end{tabular}

Other studies have pointed to gaming as a commonly preferred option also (Dias; Teixeira-Botelho, 2016).

Finally, having traced the profile of online audiovisual content viewers, the type of content they consume on each screen, what device(s) they tend to use, how often they use them, which devices they use in tandem with one another and for what purposes, and the most common types of interactive applications they use are directly linked to audiovisual content: for instance, a video game linked to a TV series or a social network discussion board relating to an entertainment program -irrespective of whether the app is used while the content itself is being viewed, or at a different moment in time. The data presented in Table 11 shows that when viewers use interactive applications that are directly linked to audiovisual content, they favor -as before- messaging services and social networks, the use of which has risen in exponential terms between 2012 and 2016.

Based on the data in Table 12, the most common action associated with using an interactive application is to express opinions or preferences in relation to the audiovisual content being viewed. In this way, a fundamental social need is met: to feel connected to others (Dias; Teixeira-Botelho, 2016; Tse, 2016). This need was first discerned in 1970s in research based on uses and gratifications theory: people look to the media to meet the basic need of strengthening interpersonal bonds (Katz; Gurevitch; Hass, 1973).

Larger screens tend to be used to watch content that requires continuous viewing and a higher level of concentration

\section{Conclusions}

Audiovisual viewing habits among the audience have been transformed by technological innovation, the popularization of Internet access via high-speed connections, the expanding range of connected devices and the convergence of the Internet with legacy media. Spanish people are hooked on lit screens and seem to avoid black mirrors -that is, switched-off screens.

This is the context in which the consumption of traditional television content peaked in 2012, followed by a downturn in the trend from 2013 onwards, falling by about a quarter an hour per day per person within a relatively short period of time, to below the four-hour threshold. Besides external factors, the reasons for this fall include the boom in the avai- lability of online and on-demand audiovisual content, produced by both traditional television channels as well as by new OTT (over-the-top-television) platforms, which offer a more flexible and tailored audiovisual service.

As mentioned before, this research project aims to bridge the gap between audience and production studies. In this regard, the following conclusions about viewing habits may influence creative decisions taken by executive producers.

The smallest-sized screens tend to be used to watch content that can be viewed in a more fragmented way or while on the move

First, the results presented here show the youngest segment of the online population (14-34 years old) is most likely to access audiovisual content via the Internet; the gender of the individual is not significant in this regard. Eight out of ten users now say they access such services online, as compared with less than half in 2012. The trend is clearly growing. Those who say that they never or almost never access audiovisual content via the Internet (the older target population segments) hold that they prefer the traditional media -that is, cinema and television.

Second, the most commonly used devices are the computer and smartphone; the growth in their use has proven exponential in recent years. Nevertheless, the use of the tablet

Table 12. Actions performed using interactive applications related to audiovisual content (2016) (\%)

\begin{tabular}{|l|c|c|}
\cline { 2 - 3 } \multicolumn{1}{l|}{} & Yes & No \\
\hline Express my opinions and preferences & 37 & 63 \\
\hline Make proposals and suggestions, etc. & 9 & 91 \\
\hline Recommend content & 24 & 76 \\
\hline Discuss with other fans & 10 & 91 \\
\hline $\begin{array}{l}\text { Contact actors, presenters, participants, or TV } \\
\text { professionals (producers, directors, etc.) }\end{array}$ & 4 & 96 \\
\hline $\begin{array}{l}\text { Contribute significant information relating to the } \\
\text { content }\end{array}$ & 9 & 91 \\
\hline Take part in polls, competitions, and/or games & 23 & 77 \\
\hline Look only at content posted by others & 8 & 92 \\
\hline $\begin{array}{l}\text { Post online videos relating to the TV programs or } \\
\text { series }\end{array}$ & 18 & 82 \\
\hline No participation & 28 & 72 \\
\hline
\end{tabular}


appears to have plateaued, and smart TVs or Internet-connected television sets do not seem to be favored by users to access online content; the latter tend to be used to watch linear or traditional television programming.

Third, in regards to the types of television content, feature films, foreign series, and news programs prove most popular. With regard to the most commonly used devices, devices with larger screens tend to be used for content that requires a higher level of concentration and continuous viewing, such as films and series. In contrast, smaller devices tend to be used for content that can be viewed in a fragmented way and while on the move.

And finally, the use of a second screen is also a very common activity. The smartphone is the preferred device for this purpose. The second screen tends to be smaller in size than the first screen, which is why smart TV or Internet-connected TV sets are rarely used as secondary option.

More than $60 \%$ of the online audience uses the second screen to avail themselves of interactive apps while viewing audiovisual content. This figure has grown steadily from 2012 to 2016. The main apps are WhatsApp (or other messaging services) and social media. Viewers tend to use these interactive apps to express their preferences and opinions, reinforcing interpersonal relationships and the need to be interconnected with others. Thus, although personalized consumption is a defining characteristic of online viewing, the social bonds associated with the communities that form around traditional media are not lost. Moreover, it is clear that technological innovation does not affect the basic needs met by the media, set out in a range of studies relating to uses and gratifications theory; rather, it affects the way in which such needs are met.

\section{Over $60 \%$ of viewers commonly use inte- ractive applications on a second device while watching audiovisual content}

These conclusions imply that audiovisual production in general, and the film and television sectors in particular, continue to face significant challenges posed by the technological disruption of the industry and changes in viewing habits. Profound uncertainties and risks have emerged in this context, although the shift may also enable valuable opportunities. More screens and content mean more opportunities to commercialize content and new ways of targeting different segments of the public. At the same time, however, it is more difficult to generate audience loyalty and to attract or retain their attention due to greater competition (traditional media content now competes with subscription video, on demand services, and vast amounts of user-generated content) and the fact that viewers tend to multitask, using a second screen while watching a primary screen.

\section{Footnote}

1. For detailed data on online audiovisual consumption in Spain in 2012, see the following publications: Diego; Etayo;
Guerrero, 2014; Diego; Guerrero; Etayo, 2014; Diego; Etayo; Guerrero, 2016.

The most common action associated with using an interactive application is to express opinions or preferences

\section{Acknowledgements}

This article is part of a subsidized research project: Identificación de los motivos de consumo de los contenidos audiovisuales de ficción y entretenimiento en el mercado español, financed by the Spanish Ministry of Economy and Competitiveness for the period 2016-18 (CSO2015-64615-R).

\section{References}

Abreu, Jorge; Almeida, Pedro; Silva, Telmo; Oliveira, Rita (2015). "Discovering TV contents in a second screen app: perspectives from Portuguese and Brazilian markets". Procedia computer science, v. 64, pp. 1240-1247. https://doi.org/10.1016/j.procs.2015.08.508

AIMC (2017). Navegantes en la Red. Asociación para la investigación de medios de comunicación.

http://www.aimc.es/-Navegantes-en-la-Red-.htm/

Alonso, Elisa; Broullón-Lozano, Manuel; Lamuedra-Graván, María (2016). "Análisis empírico de la dinámica de remediación entre la televisión e Internet en España: los discursos de los usuarios". Revista latina de comunicación social, v. 71, pp. 160-196.

https://doi.org/10.4185/RLCS-2016-1090

Anderson, Chris (2006). The long tail: Why the future of business is selling less of more. New York: Hyperion. ISBN: 1 401302378

Arrojo, María-José (2010). "Distribución y financiación de formatos audiovisuales en internet". Revista Telos: Cuadernos de comunicación e innovación, n. 85, pp. 117-128. https://goo.gl/9mBKLn

Artero, Juan P. (2010). “Online video business models: YouTube vs. Hulu". Palabra clave, v. 13, n. 1, pp. 111-123. http://www.redalyc.org/articulo.oa?id=64916293007

Bondad-Brown, Beverly A.; Rice, Ronald E.; Pearce, Katy E. (2012). "Influences on TV viewing and online user-shared video use: Demographics, generations, contextual age, media use, motivations, and audience activity". Journal of broadcasting \& electronic media, v. 56, n. 4, pp. 471-493.

https://goo.gl/rCXSNe

https://doi.org/10.1080/08838151.2012.732139

Bury, Rhiannon; Li, Johnson (2013). "Is it live or is it timeshifted, streamed or downloaded? Watching television in the era of multiple screens". New media \& society, v. 17, n. 4, pp. 592-610.

https://goo.gl/9pEUrZ

https://doi.org/10.1177/1461444813508368

Castillo-Hinojosa, Ana-María (2012). “Ficción audiovisual en redes sociales en línea: prácticas para la construcción de 
identidad y relaciones en Facebook". Revista comunicación, v. 1, n. 10, pp. 907-916.

https://goo.gl/LZ3Cnf

Choi, Boreum; Jung, Yoonhyuk (2016). "The effects of second-screen viewing and the goal congruency of supplementary content on user perceptions". Computers in human behavior, v. 64, pp. 347-354.

https://goo.gl/GFPjsh

https://doi.org/10.1016/j.chb.2016.06.048

Cunningham, Stuart; Craig, David; Silver, Jon (2016). "YouTube, multichannel networks and the accelerated evolution of the new screen ecology". Convergence: The international journal of research into new media technologies, v. 22, n. 4, pp. 376-391.

https://eprints.qut.edu.au/98716

https://doi.org/10.1177/1354856516641620

Dias, Patricia; Teixeira-Botelho, Inés (2016). "Multi-screening: Prácticas emergentes, motivaciones y expectativas". Redes.com, n. 13, pp. 273-291.

http://revista-redes.hospedagemdesites.ws/index.php/ revista-redes/article/view/380

Diego, Patricia (2015). "Estrategia multiplataforma de la televisión conectada". In: Medina, Mercedes (2015). La audiencia en la era digital. Madrid: Fragua, pp. 145-168. ISBN: 9788470746703

Diego, Patricia; Etayo, Cristina; Guerrero, Enrique (2014). "Tell me the screen you use, and I will tell you the content you watch: The case of Spanish internet users". Trípodos, $\mathrm{n}$. 35, pp. 157-177.

http://dadun.unav.edu/handle/10171/37472

http://www.tripodos.com/index.php/Facultat Comunicacio_Blanquerna/article/view/198/235

Diego, Patricia; Etayo, Cristina; Guerrero, Enrique (2016). "Multi-screen viewing and contents: Understanding connected TV". In: Lugmayr, Artur; Stojmenova, Emilija; Stanoevska, Katarina; Wellington, Robert (2016). Information systems and management in media and entertainment industries. Cham: Springer, pp. 25-46. ISBN: 9783319494074 https://goo.gl/9Tg6TU https://doi.org/10.1007/978-3-319-49407-4_2

Diego, Patricia; Guerrero, Enrique; Etayo, Cristina (2014). "Televisión conectada en España: contenidos, pantallas y hábitos de visionado". Revista mediterránea de comunicación, v. 5, n. 1, pp. 179-199.

https://doi.org/10.14198/MEDCOM2014.5.1.10

Doyle, Gillian (2010). "From television to multi-platform: Less from more or more for less?". Convergence: The international journal of research into new media technologies, v. 16, n. 4, pp. 431-449.

http://www.oecd.org/tad/services-trade/47559455.pdf https://doi.org/10.1177/1354856510375145

Doyle, Gillian (2015). "Multi-platform media and the miracle of the loaves and fishes". Journal of media business studies, v. 12, n. 1, pp. 49-56. http://eprints.gla.ac.uk/106845/7/106845.pdf https://doi.org/10.1080/16522354.2015.1027113
Doyle, Gillian (2016). “Digitization and changing windowing strategies in the television industry: Negotiating new windows on the world". Television \& new media, v. 17, n. 7, pp. 629-645.

http://eprints.gla.ac.uk/119595

https://doi.org/10.1177/1527476416641194

Evans, Elizabeth (2011). Transmedia television: Audiences, new media and daily life. New York: Routledge. ISBN: 9780 415882927

Evens, Tom (2010). "Value networks and changing business models for the digital television industry". Journal of media business studies, v. 7, n. 4, pp. 41-58.

https://goo.gl/VEQgT8

https://doi.org/10.1080/16522354.2010.11073514

Feijóo, Claudio (2013). "Soportes digitales y transformación de la industria de contenidos". El profesional de la información, v. 22, n. 1, pp. 5-9.

https://doi.org/10.3145/epi.2013.ene.01

Fernández-Manzano, Eva-Patricia; Neira, Elena; Clares-Gavilán, Judith (2016). "Data management in audiovisual business: Netflix as a case study". El profesional de la información, v. 25, n. 4, pp. 568-576.

https://doi.org/10.3145/epi.2016.jul.06

Galán-Fajardo, Elena; Del-Pino-Romero, Cristina (2010). "Jóvenes, ficción televisiva y nuevas tecnologías". Área abierta, n. 25, pp. 1-17.

http://revistas.ucm.es/index.php/ARAB/article/view/ ARAB1010130003A

Galindo-Rubio, Fernando; Fernández-Blanco, Elena; Alameda-García, David (2014). "Análisis del uso e interacción con aplicaciones second screen en TV social en España". Cuadernos.info, n. 35, pp. 159-175.

https://doi.org/10.7764/cdi.35.565

González-Aldea, Patricia; López-Vidales, Nereida (2011). "La generación digital ante un nuevo modelo de televisión: contenidos y soportes preferidos". Anàlisi: quaderns de comunicació i cultura, n. 44, pp. 31-48.

http://www.raco.cat/index.php/Analisi/article/view/248760

Guerrero, Enrique (2011). "El ecosistema multiplataforma de los grupos televisivos españoles: los formatos de entretenimiento". Comunicación y hombre, n. 7, pp. 85-103.

http://ddfv.ufv.es/handle/10641/874

Guerrero, Enrique; Diego, Patricia; Pardo, Alejandro (2013). "Distributing audiovisual contents in the new digital scenario: Multiplatform strategies of the main Spanish television networks". In: Friedrichsen, Mike; Mühl-Benninghaus, Wolfgang (eds.). Handbook of social media management. Value chain and business in changing media markets. Berlin: Springer, pp. 349-374. https://doi.org/10.1007/978-3-642-28897-5_20

Gunter, Barrie (2010). Television versus the Internet: Will TV prosper or perish as the world movies online?. Oxford: Chandos Publishing. ISBN: 9781843346364

Instituto Nacional de Estadística (2017). http://www.ine.es 
Izquierdo-Castillo, Jessica (2012). “Distribución online de contenidos audiovisuales: análisis de tres modelos de negocio". El profesional de la información, v. 21, n. 4, pp. 385-390. https://doi.org/10.3145/epi.2012.jul.09

Katz, Elihu; Gurevitch, Michael; Hadassah, Hass (1973). "On the use of the mass media for important things". American sociological review, pp. 164-181 https://goo.gl/9yDMzg

Jenkins, Henry (2006). Convergence culture: Where old and new media collide. New York: New York University Press. ISBN: 9780814742815

Jenkins, Henry; Ford, Sam; Green, Joshua (2013). Spreadable media: Creating value and meaning in a networked culture. New York: New York University Press. ISBN: 9780 814743508

Jiyoung, Cha (2013). "Do online video platforms cannibalize television? How viewers are moving from old screens to new ones". Journal of advertising research, v. 53, n. 1, pp. 71-82. https://goo.gl/ghUW1z http://doi.org/10.2501/JAR-53-1-071-082

Kantar Media (2016). TV Audience ratings. http://www.kantarmedia.com/global

Kim, Jin (2012). "The institutionalization of YouTube: From user-generated content to professionally generated content. Media, culture \& society, v. 34, n. 1, pp. 53-67. https://goo.gl/w1Dzc7 http://doi.org/10.1177/0163443711427199

Lacalle, Charo (2011). "La ficción interactiva: televisión y web 2.0". Ámbitos, n. 20, pp. 87-107

http://www.redalyc.org/html/168/16821321005/

López-Vidales, Nereida; Gómez-Rubio, Leire (2014). “Nuevos hábitos de los jóvenes españoles y tendencias de futuro en el consumo de radio y televisión". Historia y comunicación social, n. 19, pp. 327-340.

https://doi.org/10.5209/rev_HICS.2014.v19.45031

Mayer, Vicki (2016). "The places where audience studies and production studies meet". Television \& new media, v. 17, n. 8, pp. 706-718.

https://doi.org/10.1177/1527476416652482

Méndiz, Alfonso; De-Aguilera, Miguel; Borges, Eddy (2011).
"Actitudes y valoraciones de los jóvenes ante la TV móvil". Comunicar, v. 13, n. 36, pp. 77-85.

http://doi.org/10.3916/C36-2011-02-08

Micó-Sanz, Josep-Lluís (2011). “Entretenimiento transversal. Convergencia de contenidos entre la televisión, internet y los dispositivos móviles". Trípodos, n. 27, pp. 107-115. http://www.raco.cat/index.php/Tripodos/article/view/234161

Napoli, Philip M. (2011). Audience evolution: New technologies and the transformation of media audiences. New York: Columbia University Press. ISBN: 9780231150347

Park, Yuri (2013). "Changes in TV viewing habits: an empirical analysis of second screen usage". Asian journal of information and communications, v. 5, n. 1, pp. 34-44 https://goo.gl/ZR3W8F

Palmer, Shelly (2006). Television disrupted: The transition from network to networked TV. Boston: Focal Press. ISBN: 9780240808642

Taneja, Harsh; Webster, James G.; Malthouse, Edward C.; Ksiazek, Thomas B. (2012). "Media consumption across platforms: Identifying user-defined repertoires". New media \& society, v. 14, n. 6, pp. 951-968.

https://doi.org/10.1177/1461444811436146

Tapscott, Don (2009). Grown up digital: How the net generation is changing your world. New York: MacGraw-Hill Professional. ISBN: 9780071508636

Tse, Yu-Kei (2016). “Television's changing role in social togetherness in the personalized online consumption of foreign TV". New media \& society, v. 18, n. 8, pp. 1547-1562. https://doi.org/10.1177/1461444814564818

Ulin, Jeffrey (2013). The business of media distribution: Monetizing film, TV and video content in an online world. Burlington: Focal Press. ISBN: 9780240824239

Vogel, Harold L. (2014). Entertainment industry economics: A guide for financial analysis. New York: Cambridge University Press. ISBN: 9781107075290 https://doi.org/10.1017/CB09781139871679

Vukanovic, Zvezdan (2009). Television and digital media in the $21^{\text {st }}$ century: New business, economic and technological paradigm. Novi Sad: Media Art Service International. ISBN: 9788685831164

\section{Cronología de la Documentación Española}

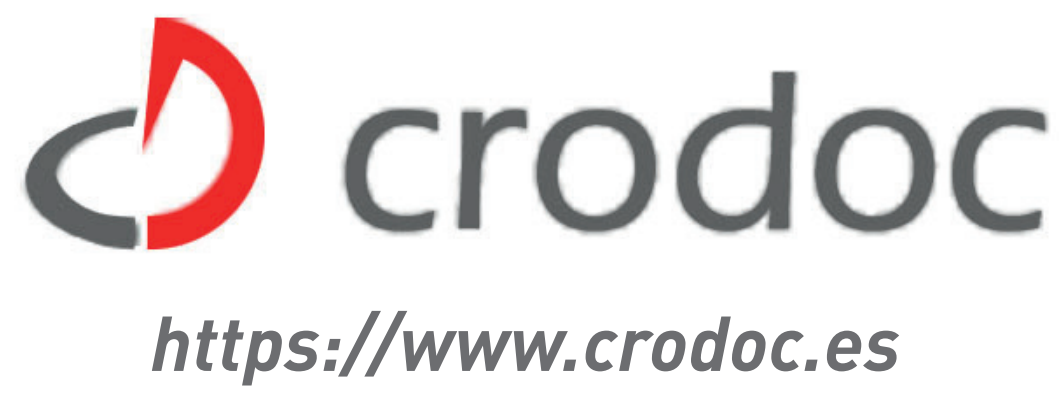


a $2,7,01$ मान revisers

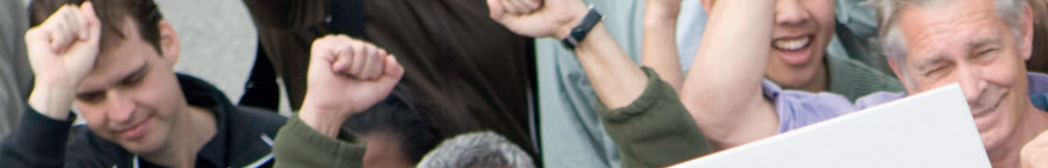

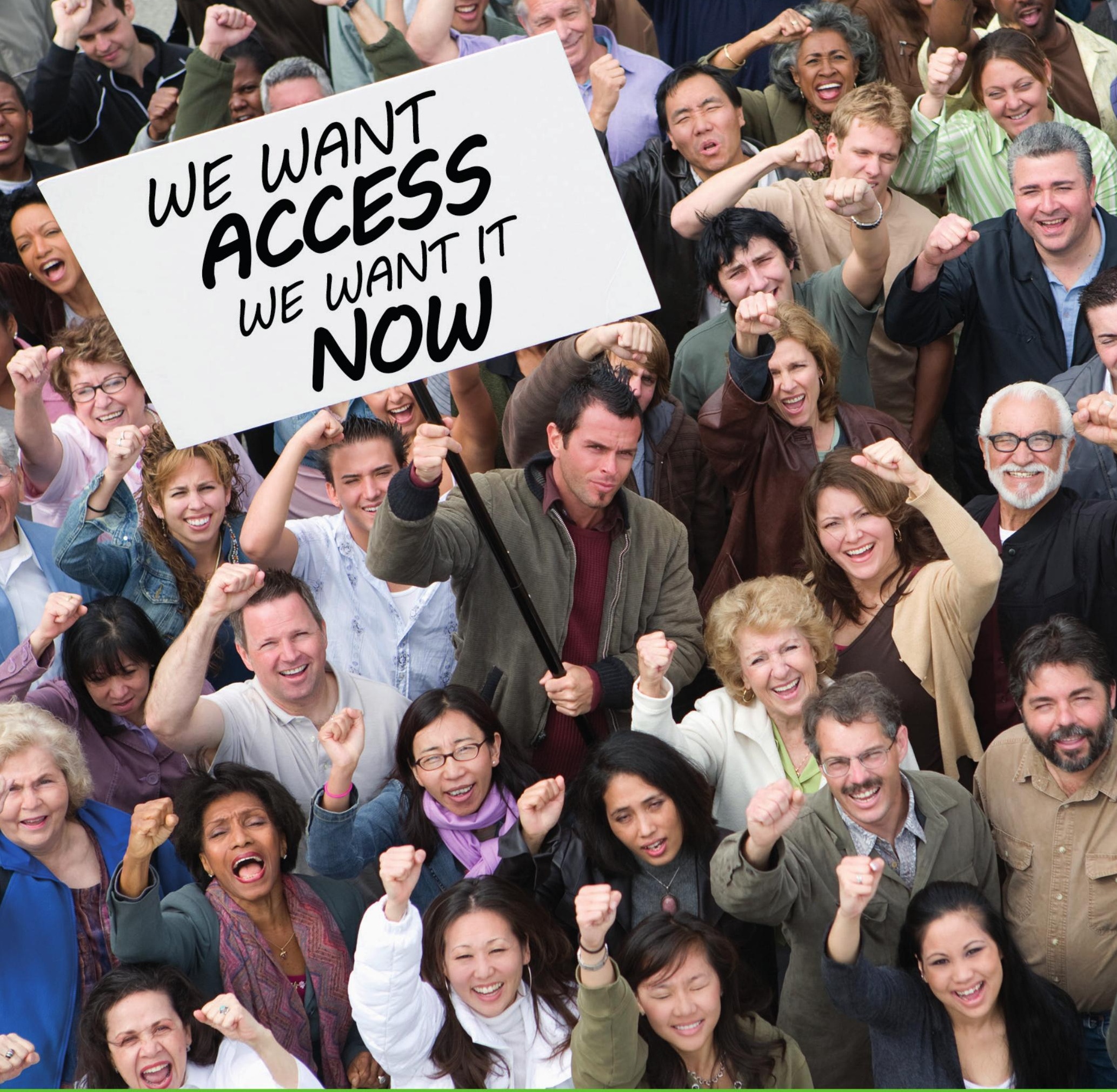

20 años diseñando

y gestionando información

MASmedios apoya la Declaracion de Lyon del 2014 que

propugna el derecho de las personas a acceder a la información. masmedios

www.masmedios.com 